\title{
Validating the combination Cerastium dichotomum var. inflatum (Caryophyllaceae)
}

\section{Shahina A. Ghazanfar ${ }^{1}$}

Summary. A new combination Cerastium dichotomum var. inflatum invalidly published in Flora of Iraq Volume 5 Part 1 is here validated.

Key Words. Iraq, new combination, nomenclature.

\section{Introduction}

In the treatment of Caryophyllaceae in Flora of Iraq 5 (1), published 2016, it was pointed out to me by members of the IPNI team that the new combination Cerastium dichotomum L. var. inflatum (Link) Kandemir was not validly published.

In this communication, I attempt to rectify this.

Cerastium dichotomum L. var. inflatum (Link) Kandemir was published as a new combination (comb. et stat. nov.) in Flora of Iraq 5 (1): 53 (Kandemir 2016), based on Cerastium inflatum Link in Tabl. École Bot. ed. 3: 462 (Link 1829).

This combination is invalid as it was based on an invalidly published basionym, contrary to Art. 41.5 of the ICN (2012).

The names Cerastium inflatum Link (1829) and C. inflatum Link ex Sweet in Hort. [Sweet]. ed. 2, 57 (Sweet 1830) were invalidly published, without description (see IPNI). Boissier validated the name C. inflatum Link in Flora Orient. [Boissier] 1: 721 (Boissier 1867).

Based on Boissier's publication, the new combination for Cerastium dichotomum L. var. inflatum and its full synonymy is as follows:

Cerastium dichotomum L. var. inflatum (Link ex Boiss.) Kandemir ex Ghaz. comb. et stat. nov.

http://www.ipni.org/urn:lsid:ipni.org:names:60473797-2

Basionym: Cerastium inflatum Link ex Boiss., Fl. Orient. [Boissier] 1: 721 (Boissier 1867). Syntypes:
Montibus Akdagh et Beydagh Syriae, Haussknecht (?JE); Syriae et Arabiae petreae, Boissier (G-Boiss.); Persia australis inter Persepolim et Shiraz, Kotschy 139 (K!); Yezd, Bushe et boreali ad Tehran, Bunge, Belutschia, Stocks (K!).

C. inflatum Link (1829: 462), nom. inval. nom. nud.

C. inflatum Link ex Sweet (1830: 57), nom. inval. nom. nud.

C. dichotomum L. subsp. inflatum (Link) Cullen (1967: 211), nom. inval.

C. dichotomum L. var. inflatum (Link) Kandemir (2016: 53), nom. inval.

\section{Acknowledgements}

I am grateful to Irina Belyaeva, Rafaël Govaerts, Helen Hartley and Heather Lindon for bringing this to my attention and help with correct nomenclature.

Open Access This article is distributed under the terms of the Creative Commons Attribution 4.0 International License (http://creativecommons.org/ licenses/by/4.0/), which permits unrestricted use, distribution, and reproduction in any medium, provided you give appropriate credit to the original author(s) and the source, provide a link to the Creative Commons license, and indicate if changes were made.

\section{References}

Boissier, P. E. (1867). Flora Orientalis 1: 721. H. Georg, Genevae, Basileae, Lugduni.

\footnotetext{
Accepted for publication 7 February 2017. Published online 4 April 2017

1 Royal Botanic Gardens, Kew, Richmond, Surrey, TW9 3AB, UK. e-mail: s.ghazanfar@kew.org
} 
Cullen, J. (1967). In: I. Hedge et al., Notes Roy. Bot.Gard. Edinburgh. 27: 211.

ICN (2012). J. McNeill, F. R. Barrie, W. R. Buck, V. Demoulin, W. Greuter, D. L. Hawksworth, P. S. Herendeen, S. Knapp, K. Marhold, J. Prado, W. F. Prud'homme Van Reine, G. F. Smith, J. H. Wiersema $\&$ N. J. Turland (eds), International Code of Nomenclature for algae, fungi, and plants (Melbourne Code). Regnum. Veg. 154. Koeltz Scientific Books. http:/ /www.iapt-taxon.org/nomen/main.php

IPNI (continuously updated). http://ipni.org/index.html
Kandemir, A. (2016). Kandemir In: S. A. Ghazanfar \& J. R. Edmondson (eds), Flora of Iraq Volume 5 (1), Elatinaceae to Sphenocleaceae: 53. Published on behalf of the Ministry of Agriculture Republic of Iraq by Royal Botanic Gardens, Kew.

Link, J. H. F. (1829). Tableau de l'école de botanique du Muséum d'histoire naturelle, ed. 3 (Cat. Pl. Horti Paris): 462. J. S. Chaudé, Paris.

Sweet, R. (1830). Sweet in Hortus britannicus, ed. 2: 57. James Ridgway, London. 